\title{
SPACE IN ORGANISATION AND MANAGEMENT. INTERDISCIPLINARY PERSPECTIVE IN MODELLING TOWARDS NEW MANAGERIAL ROLES
}

\section{Piotr Pachura}

\section{Introduction}

The concept of space is frequently used as a sort of metaphor, with the aim of referring to a colloquial, intuitive interpretation of space as a kind of location, area, field or scene where events take place. Recognisable research problems stem from the conviction that there is a lack of complex conceptualisation of space as a subject in interdisciplinary perspectives for organisation and management sciences. At the same time, a greater interest in issues of space has arisen in recent years, which have been associated with the increasing importance of globalisation, the network economy, and knowledge in organisations (Taylor \& Spicer, 2007). Thus, understanding complex interdisciplinary research in this area is the main motivation of this paper. On an epistemological level, the aim of the paper is to conceptualise space in its different dimensions in relation to the classical achievements of organisation and management sciences. Another aim is to derive a metaphorical understanding of space; therefore, the starting point and subsequent context of this research is placing the research problem in the scientific tradition. In this paper, I try to make a logical transition from space ontology, through the conceptualisation of its dimensions, to its theoretical implications. As Massey, one of the authorities in "space science" observes, "we use that word 'space' in popular discourse or academia without being fully conscious of what we mean by it" (2005, p. 17).

Methodologically, this paper aims to develop the idea of space and its role in organisations in the context of emergence a new managerial roles. The deductive method was applied, leading from wide interdisciplinary studies through construction of a conceptual model as the meta-level (Space Organisation Model,
SOM), to theoretical experiments at the microlevel (New Managerial Roles). The experiment was a confrontation between the conceptual model and the managerial roles in modern organisations.

\section{Space in a Transdisciplinary Perspective}

\subsection{Philosophy of Space}

Probably the first scientific, philosophical argument concerning the subject of space was the discussion over vacuum initiated by the ancient schools of natural philosophers (Parmenides 540-470 BC). The Atomists (Democritus 460-370 BC, Epicurus 341-271 $\mathrm{BC})$ recognised space as a container where all physical phenomena take place. Idealistic philosophy, mostly represented by Plato (427347 BC), interpreted space (Greek khôra, chora) as a sphere that is a combination or transition between a material and a metaphysical sphere (Beichler, 1981). The Platonic concept of chora is considered a predecessor of the concept of space and was closely associated with the Platonic philosophy system based on the duality of an imperfect world of matter and a perfect world of ideas. On the other hand, Aristotle (384-322 BC) recognised that the world has borders, i.e. the space in the world is finite (Hussey, 1983). At the same time, Aristotle believed that nature abhors a vacuum. Reflection on space was partially discarded in the period of Scholastic philosophy. A revival of interest in space can be observed in the period of modern philosophy and development of empirical sciences. For example, R. Descartes, (1569-1650) assumed that an empty space (vacuum) could not exist due to the assumption that the extension of matter (Latin res extensa) is one of its basic characteristics. 
These extensions all have spatial properties, therefore the characteristics of matter should be considered spatially (Descartes, 2008). In contrast, I. Newton (1642-1727) formulated an assumption that absolute space is permanent, objective, and independent of relationships (Fraassen van, 1985, p. 124). The consequence of the absolute space concept is that its existence must be acknowledged, regardless of matter and time (Newton, 1999). Meanwhile, W. Leibnitz (1646-1716) claimed that space in itself is not an absolute reality; it is merely a configuration of matter. He presented a broad relativistic approach, also assuming that space is neither substance nor phenomenon. However, according to I. Kant (1724-1804), space is a form of pure intuition, (ger. Anschauung) - an object of direct perception that does not result from experience. According to Kantian philosophy, space is a form of a priori which is given to the human mind without the necessity of external experience (Kant, 1992). Space is a representation of a priori knowledge, just as (Euclidean) geometry is able to be recognised through the imagination embedded in the human mind (Caygill, 1995). Experiencing the "spatiality" of the world has been a key human experience throughout the development of Civilisation (Schemmel, 2016).

\subsection{Geometry of Space}

In the context of the above considerations on space, one should refer to the achievements of geometry as a specific language of describing space. Euclid (365-300 BC) created a concept of space based on a group of undefinable primitive terms and the resulting axioms (Fraassen van, 1985 , p. 132). Euclid's concept of space as a geometric category precluded interest in space as a non-mathematical category for many years. For over two thousand years, when people thought of space, they understood it in terms of Euclid's "language" of geometry. Classical geometry was challenged by $\mathrm{N}$. Lobachevsky (1792-1856), who created a consistent system of geometry based on modified Euclidean axioms (Greenberg, 1994). Independently of Lobachevsky, a similar approach was applied by J. Bolyai (1802-1860), thus explaining why the first non-Euclidean geometry system is called Bolyai-Lobachevskian geometry, or hyperbolic geometry (Cannon et al., 1997). A significant contribution to the interpretation of space through hyperbolic geometry models was provided by $\mathrm{H}$. Poincaré (1854-1912), who recognised the human perception of space to be the result of evolution, i.e. he assumes that our understanding of space is derived from the conditions of adapting to the world in which we live. In contrast to Kant, Poncaré believed that geometry is not given to human cognition a priori (Heinzmann \& Stump, 2016). He believed that space is a relational or relative concept. Consequently, he is attributed with a very significant contribution to the development of the theory of relativity that was presented decades later in its final form. However, the explanation offered by non-Euclidean geometries did not answer all questions regarding the observed physical world and the geometric forms found in nature. More contemporary research in geometry and the dynamics of disordered dynamic systems led to the development of the principles of fractal geometry. The concept of fractals results from the observation that the reality that surrounds us has geometric properties of similarity, i.e. the occurrence of repetitive geometrical structures (Mandelbrot, 1982). Such structures, while seemingly irregular, show geometric similarities at different levels of complexity. The development of nonEuclidean geometries resulted in an increase in the potential of space research. However, the space we experience is probably a Euclidean space; we experience it as a continuous and three-dimensional space.

\subsection{Classic Approach to Space in Organisations and Management}

Classically, for management science, space exists in the context of intra-organisational and external space (usually called the environment of the organisation). This is a kind of absolutist understanding of space used for interpreting, for example, the physical arrangement of individual elements of a production system or a hierarchical system associated with the workplace, taking into account the managerial and operative functions. In the early works of F. Taylor (1967), space was interpreted in terms of physical location. At the same time, the importance of space is found in the categories of physical productivity or space associated with the division of labour and organisation of production. H. Ford's production line in some way perpetuated the mostly physical locational context of space over the next few decades. Such an approach to space resulted 
in relatively clear boundaries between space inside the organisation and the boundaries between the organisation and its environment. At the same, space was the exemplification of hierarchism in organisations: a specified system and plan of space in the workplace (production halls, offices) corresponded to the position of individual members in the hierarchy of the organisation (Derksen, 2014). We can also observe that the administrative school represented by M. Weber (Weber, 1947) creates, in a way, a new universalistic representation of an organisation's space that is associated with the spatial location of "bureaucracy". Bureaucratic space represents depersonalised power that acts in the interest of a common good not by creating interpersonal relationships, but rather by focusing on the relationship between a person and the spatial representation of power. A major turning point in the interpretation of space in management sciences was the development of the human relations movement. The classic work of E. Mayo, based on Hawthorne's experiments, involved research on job performance (efficiency) and group dynamics (Mayo, 1933). It can be said that this allowed them to identify organisational space that consists of relational space, the values sphere (symbolic), and the space of a place. As a generalisation, it can be said that most research approaches treat the issue of space as a kind of metaphor that is most often associated with the so-called "organisation environment" or "organisation boundaries". However, the "organisation environment" concept does not tell us much about space. In the classic interpretation, there was a dominant approach that recognised a distinction between the organisation and the environment: something was "inside" and something was "outside" the organisational space. It seems that we can find here a classic Aristotelian understanding of space as a "container" or "vessel" where material beings can be found and various phenomena occur.

\subsection{Contemporary Space Studies in Organisation and Management Sciences}

As Kornberger and Clegg claim, "In terms of more classical academic foundations, space has long been an implicit concern of organisation theory" (2004, p. 1096). However, it is worth noting some important developments in this area that introduce space into the scientific discussion, in the theory of organisation and management, the work of Clegg and Kornberger (2013), Lekanne Deprez and Tissen (2008), Lorenzen (2007), Ropo, De Paoli and Solovaara (2015) and others deserves attention. It seems that an important point of reference for the scientific discussion of space in the organisation sciences is the influential concept of the "production of space" by H. Lefèbvre. Most references to this concept are probably found in works on the sociology of organisations (Zhang et al., 2008). Lekanne Deprez and Tissen (2008) recognise that organisational space is divided into physical space, virtual space, and mental space, and this interpretation is inspired by the aforementioned theory of Lèfebvre. It must be emphasised that space research in the context of organisation and management is most often found at the frontier of various scientific disciplines, therefore it has a strongly interdisciplinary character. As Chanlat notes, "In the field of organisation studies, space has been the preserve mainly of researchers drawn from psychology, social psychology, sociology, anthropology and geography" (2013, p. 17). Vaujany and Mitev classify the main research approaches in space by listing, inter alia, economic geography, theory of localisation, environmental psychology, sociology of space in organisations, sociology of architecture in organisations, as well as sociomateriality in organisations (2013, p. 4-6). It seems that research on "space theories" that is directly related to the theory of organisations and management can be summarized as shown in Tab. 1.

\section{In Search of Space Dimensions in Organization}

\subsection{Global-Local and Networked Space}

In social and economic studies, the concept of place and space is known mostly from the work of Castells, who introduced the concept of the so-called "space of flows", which involves interpretation of the dichotomy associated with the classically understood space of a place, contrasting it with the space of flows (Castells, 2000). From Castells' perspective, space is neither an absolute category, nor a scene of events, nor a container that houses phenomena. Rather, it is created by a system of social relationships (such interpretation of space is consistent with Leibniz, as mentioned above). 


\begin{tabular}{|c|c|c|}
\hline Research stream & $\begin{array}{l}\text { Key features } \\
\text { of analysis }\end{array}$ & Description \\
\hline $\begin{array}{l}\text { Sociology } \\
\text { of organisations }\end{array}$ & $\begin{array}{l}\text { Relationship between } \\
\text { organisation and } \\
\text { environment, social } \\
\text { meaning of organisation, } \\
\text { bureaucracy and } \\
\text { post-bureaucracy, } \\
\text { organisational culture. }\end{array}$ & $\begin{array}{l}\text { This stream is generally derived from sociology, } \\
\text { anthropology, psychology, as well as from classic } \\
\text { theories of interpersonal relations (Brunet-Thornton \& } \\
\text { Bureš, 2012). The approaches show the importance of } \\
\text { the organisation of space as a social landscape and the } \\
\text { role of spatial practices and spatial representation in } \\
\text { organisations, particularly with respect to organisational } \\
\text { control (e.g. Halford, 2004). This research approach } \\
\text { may be linked to earlier achievements within the } \\
\text { concept of social production of space by Lefebvre } \\
\text { (1991), which recognises space as a social product. }\end{array}$ \\
\hline $\begin{array}{l}\text { "Sociomateriality" } \\
\text { in organisations }\end{array}$ & $\begin{array}{l}\text { Spatial structure } \\
\text { in organisations, } \\
\text { sociomaterial } \\
\text { configurations, } \\
\text { organisational control, } \\
\text { facility management. }\end{array}$ & $\begin{array}{l}\text { This stream is generally derived from postmodernist } \\
\text { traditions, structuration theory (Roth, Sales, } \\
\& \text { Kaivo-oja, 2017), and actor-network theory. } \\
\text { The research examines the context of space } \\
\text { in the organisation and focuses mainly on the issues } \\
\text { of organisation of space as a physical workspace } \\
\text { or a work environment (e.g. Beard \& Price, 2010). This } \\
\text { approach emphasises the importance of space as a way } \\
\text { to integrate people, architecture, technical equipment, } \\
\text { and organisation management practices (e.g. Price, } \\
2007) \text {. As noted by Dale and Burrell, "we hope to see } \\
\text { how the analysis of organisation becomes more aware } \\
\text { of space, embodiment and materiality." (2007, p. 8). }\end{array}$ \\
\hline $\begin{array}{l}\text { Knowledge } \\
\text { and innovations } \\
\text { in organisations }\end{array}$ & $\begin{array}{l}\text { Innovation, knowledge } \\
\text { diffusion, organisational } \\
\text { networks, creativity. }\end{array}$ & $\begin{array}{l}\text { This stream generally is derived from knowledge } \\
\text { management (Kačerauskas, 2016), human } \\
\text { geography, and regional science. The research } \\
\text { approach focuses on the relationship between } \\
\text { innovative processes in organisations and physical } \\
\text { space (distance, proximity), but also examines other } \\
\text { dimensions of space such as cognitive, social, cultural } \\
\text { (Vetráková \& Smerek, 2016) organisational, and } \\
\text { institutional, interpreted as proximities (e.g. Boschma, } \\
\text { 2005; Carrincazeaux, 2008). This approach is also } \\
\text { associated with conceptualisation of contextual space } \\
\text { in organisations; these studies were initiated mainly by } \\
\text { Japanese researchers (e.g. Nonaka \& Konno, 1998; } \\
\text { Nonaka \& Takeuchi, 1995) and other scholars. }\end{array}$ \\
\hline $\begin{array}{l}\text { Internationalisation } \\
\text { of organisations } \\
\text { and globalisation }\end{array}$ & $\begin{array}{l}\text { Spatial configurations of } \\
\text { organisational networks, } \\
\text { Global Commodity } \\
\text { Chains, Global } \\
\text { Value Chains, Global } \\
\text { Production Networks. }\end{array}$ & $\begin{array}{l}\text { These studies are generally derived from } \\
\text { economic geography and are mainly focused } \\
\text { on conceptualisation of space for international } \\
\text { managerial practice in transnational corporations, on } \\
\text { the dynamics of the processes of inter-organisational } \\
\text { relations architecture (Gereffi et al., 2005; Jones, } \\
2009 ; \text { Yeung \& Coe, 2014), as well as on hierarchy } \\
\text { of organisational power (Coe, 2012). The results of } \\
\text { these studies are intended to be used in managerial } \\
\text { practice associated with leadership in international } \\
\text { organisations and decision-making processes in } \\
\text { globalising business (e.g. Schlunze et al., 2012). }\end{array}$ \\
\hline
\end{tabular}


Castells says that "space is an expression of society" (Castells, 2000, p. 440); thus, the social changes caused by globalisation and technology lead to the emergence of new forms of space, i.e. Lefebvre's "production of space", which views "(social) space as a (social) product" (Lefebvre, 1991, p. 26). In the dialectical tradition represented by Lefèbvre, space through various methods of control and specific "selfmarketing" becomes a manifestation of a liberal capitalist world order. In this interpretation, space becomes a "commodity". Therefore, we can assume that production (creation) of space can be an important manifestation of the strategy of an organisation. Giddens, like Castells, sees globalisation as a process of social relations that is shaped through space. In that sense, local processes are shaped through global processes (Giddens, 1990, p. 64). Thus, a key challenge to management theory is to look at organisation management in relation to fundamental changes in realityas a departure from the homogeneous image of space towards analysis of the formation and preparation of new spaces as a key aspect of globalisation (Chan Kim \& Mauborgne, 2005). At the same time, attention should be paid to the critical streams related to globalisation processes that are most often associated with the postmodern tradition. Postmodernism questions the traditional cannons of objectivity: it interprets reality and classic methods of investigating the truth, and thus the research approaches derived from rationalistic premises. At the same time, it undermines the conviction about the broadly defined "development" and "grand narratives" that are also related to the "narrations" of globalisation.

We are functioning in a "networked world", one consequence of which relates to the functioning of the organisation on the level of its specific physical location in specified geographical space; on the other hand, organisations have uninterrupted relations with the global economy in a space without a specified physical location. Hence, there is a belief that that the functioning of companies in inter-organisational networks poses the greatest challenge to management theory (Antolín-Lopez et al., 2015). Generally speaking, most classic approaches to analysis of inter-organisational networks are based on research into processes, which begins from acquisition of raw materials, through their transformation, and ending with their consumption (Hughes \& Reimer, 2004). In these orientations, we usually describe a sequence of actions (processes) as a system, chain, or network presented vertically (Lenz, 1997). It can be suggested that in its theoretical and practical aspects, modern management science faces challenges associated with companies striking a balance between localism, globalism, and networking. Classically understood management is gradually becoming an "obsolete" practice in terms of, for example, the traditional functions of management or organisational structures (Deprez \& Tissen, 2009). The classic approach to the spatial organisation of a company used to be based on the presence of hierarchical structures that had strong boundaries in relation to "the environment". Blurred and faded organisational boundaries leads to the formation of "postbureaucratic" structures (Bolin \& Härenstam, 2008) that are increasingly open and are based on outsourcing or structures of a virtual nature. At the same time, Graeber draws attention to the increasing importance of bureaucratic culture in the context of the dominance of transnational corporations (2015, p. 78). The widely noticeable process of blurring the boundaries of the organisation in relation to the dynamics of the surrounding space enforces more complex methods of adaptation for companies.

\subsection{Spaces "between"}

Organisation sciences and management practice have a clear contextual feature: they create a space of context and at the same time they are shaped by that context (Billsberry \& Birnik, 2010). The concept of context is used as a definition of a web of linked and interdependent factors that are necessary for effective communication and a common understanding of phenomena. Contextual (topical) understanding of space is formed on the basis of relations between the subject and the individually experienced physical space of place. Users of a common space direct their activities and actions not directly to other participants, but to the space (Lorenzen, 2007). In this case, knowledge clearly requires context that results from the relations taking place in a specific space and in real time. Space affects meaning: it produces meaning and allows the creation of meanings like silence, without which there is no music. For example, the spacing between words makes sense in a sentence. 
Thus, space is a very important part of culture, society, and organisations. "Space is more than distance. It is the sphere of open configurations within multiplicities" (Massey, 2005, p. 91). Given that, a very important question which is raised by the increased rate of communication and by cyberspace is not whether space will be annihilated, but what kinds of multiplicities and relations will be co-constructed?

Virtualisation regards most of the areas in which humans, organisations, societies, and, to some extent, things (material objects) are active (Flyverbom et al., 2016). In various postmodernist perspectives, we can note some kind of post-reality. We may conclude that one of the key approaches to the description of the post-modern world was J. Baudrillard's concept of "simulacra". (Latin simulacrum), which, in some respects, are "copies" of reality, simulations of images of reality, or "detachment" from the reality of the world of signs and cultural codes (Baudrillard, 1981). The source of such descriptions of reality should probably be sought in a Platonic understanding of the world as a "reflection" of ideal beings in the world. In contrast to Platonic ideas, however, it not the Absolute, but people who create the artificial, simulated reality. Cyberspace as a metaphorical space is clearly "spatialised", i.e. described in categories associated with spatial concepts such as "to be on-line", meaning to be in network space, or "to surf the Internet", that is to move through or roam the space of the Internet. Such concepts as the geography of the network or network architecture are also used in reference to the physical space of the real world. Different references to space (in this case, actually existing physical space) include network infrastructure or the physical arrangement of individual material elements in the form of computers, servers, and other equipment necessary for the existence of cyberspace. In the context of a phenomenological approach, it should be noted that from the point of view of humans experiencing the world, the most important aspect is the very essence of experiencing. It may be the case that the boundaries between physical space and cyberspace are fading. One of the most common behaviours in cyberspace is, for example, that users try to develop and personalise it by implementing images of the real world in the form of photos or images. Cyberspace creates new places or new spaces for new experiences. Strategies of companies are increasingly oriented towards creating new "behaviour spaces". Therefore, the product becomes an opportunity to implement consumer activities that result from the personal motivation associated with needs such as exchange of information, emotions, interests, self-realisation, knowledge, participation, etc. For a consumer, the value does not come from "the outside" as it does with classic business models, but it is collaborative, "in space".

\begin{tabular}{|c|c|c|}
\hline (P1) & Space of organization & $\begin{array}{l}\text { "Space of organisation" refers to the classical understanding of } \\
\text { space presented primarily in classical approaches based on duality; } \\
\text { "organisation and its internal space versus the external environment } \\
\text { of the organisation". }\end{array}$ \\
\hline (P2) & $\begin{array}{l}\text { Glocal space (between } \\
\text { locality and globality) }\end{array}$ & $\begin{array}{l}\text { "Glocal space" refers to a "merging" of the organisation between } \\
\text { localness and globalness; most modern organisations have } \\
\text { a physical location in a particular space and at the same time they } \\
\text { remain in constant connection with the global space. }\end{array}$ \\
\hline (P3) & $\begin{array}{l}\text { Contextual space } \\
\text { (topical space) }\end{array}$ & $\begin{array}{l}\text { "Contextual space" refers to the usually intangible meaning of space } \\
\text { related to social context, culture, and language. }\end{array}$ \\
\hline (P4) & Cyberspace & $\begin{array}{l}\text { "Cyberspace" is an artificial space; it is most often produced by } \\
\text { organisations and becomes a field of activity and value for the } \\
\text { consumer, it is also a network architecture. }\end{array}$ \\
\hline
\end{tabular}




\subsection{Conceptual Model of Space for Organization}

The first stage in this research comprised the interdisciplinary literature review that covered different notions of space, including philosophy, geometry, partly natural sciences, economics, and evolution of management. The review was aimed at reaching the essence of the notion of space from an ontological perspective.
The next step consisted of specifying the meaning and existence of space from the point of view of contemporary organisations. According to these considerations, four main dimensions of "spatiality" from the perspective of organisations are proposed (Tab. 2).

Additionally, the conceptualization research was extended and three spatial dimensions were identified in each of the four categories (Tab. 3).

\begin{tabular}{|c|c|c|}
\hline (P1) & Space of organization & $\begin{array}{l}\text { (P1.1) internal organisational space, } \\
\text { (P1.2) external organisational space (organisation environment), } \\
\text { (P1.3) organisational structures. }\end{array}$ \\
\hline (P2) & $\begin{array}{l}\text { Glocal space } \\
\text { (between locality } \\
\text { and globality) }\end{array}$ & $\begin{array}{l}\text { (P2.1) network space, } \\
\text { (P2.2) global space, } \\
\text { (P2.3) local (location) space. }\end{array}$ \\
\hline (P3) & Contextual space & $\begin{array}{l}\text { (P3.1) cultural space, } \\
\text { (P3.2) space of place, } \\
\text { (P3.3) space of context. }\end{array}$ \\
\hline (P4) & $\begin{array}{l}\text { Cyberspace (virtual } \\
\text { space) }\end{array}$ & $\begin{array}{l}\text { (P4.1) network space (network architecture, geography of network), } \\
\text { (P4.2) space of experience, } \\
\text { (P4.3) production of space. }\end{array}$ \\
\hline
\end{tabular}

Source: own

This separation of spatial dimensions was the basis for the theoretical Space Organisation Model (SOM). The construction of the model's geometry was strictly related to representation of the four categories of space mentioned above (P1, P2, P3, P4) in the form of the model (Fig. 1).

In the course of further analysis, key relations between the various dimensions of space were also identified by the following dependencies (Tab. 4).

The further process of the model's conceptualisation depicts the relations (interactions) between the individual vertices that formed contact points (Tab. 4). As a result of this transformation, we acquired the connections in the two-dimensional space of the four vertices P1.2 - P2.3; P2.2 - P3.1; $\mathrm{P} 3.3$ - P4.2, and P4.1 - P1.3. To make up for the missing relations between the P1.1 - P3.2 and P2.1 - P4.3 vertices, a "fractal" approach that involved joining (combining) the P1.1 and P3.2 vertices as well as the P2.1 and P4.2 vertices through geometric self-similarity (shown in Fig. 2) was applied. By applying the connections in accordance with the fractal approach, it is possible to create self-repeating geometrical figures that represent the model and its development towards a specific spatial structure. Fig. 2 presents a possible depiction of such a structure.

\section{New "Spacial" Managerial Roles in Organization}

The cognitive experiment was conducted with respect to the classical concept of the managerial roles of an organisation in terms of their spatial relevance in its functioning. It should be emphasised that the author is aware of many different approaches and research proposals in terms of the constantly 


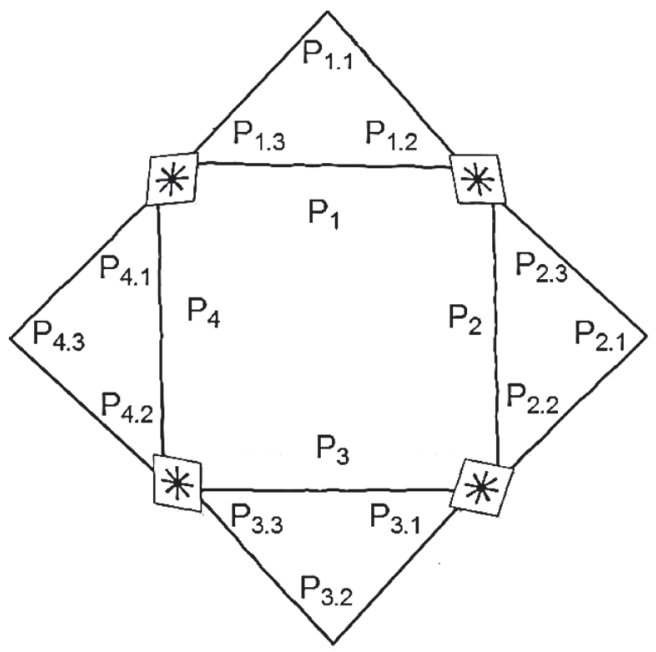

Source: own

\section{Tab. 4: Identification of key relations between the dimensions of spatiality}

(P.1), (P1.1) Contextual space of place has a close relation to internal organisational space. This and (P.3), (P3.2) $\quad$ space within its boundaries.

(P.2), (P2.1) Production of space is directly associated with network space within the meaning and (P.4), (P4.3) of inter-organisational networks. In network space (for example, in Global Production Networks), from the organisational point of view the process of creating new space occur through its "expansion", "extension", and "transformation.

(P.1), (P1.2) External organisational space (environment) is directly associated with global space.

and (P.2), (P2.3) Global space is part of external organisational space, which acts as an important part

(P.2), (P2.2) and (P.3), (P3.1)

(P.3), (P3.3) and of its environment. directly interacts with the cultural space present in a physical space.

(P.4), (P4.1) and Contextual space - a space of cultural, social, and cognitive experience, both for the social environment of the organisation and consumers - directly interacts with the space of experience, defined as the economy of the cyberspace experience phenomenon.

(P.1), (P1.3)

Organisational structures as part of "organisational space" or its form remain in relation to network architecture, primarily because network architecture (e.g. physical arrangement of individual elements of the technical infrastructure of a network) may influence the organisational structure and its design as well as the network architecture itself. Its usage by an organisation may be a prerequisite for adopting a specified organisational structure, e.g. so-called virtual companies. 


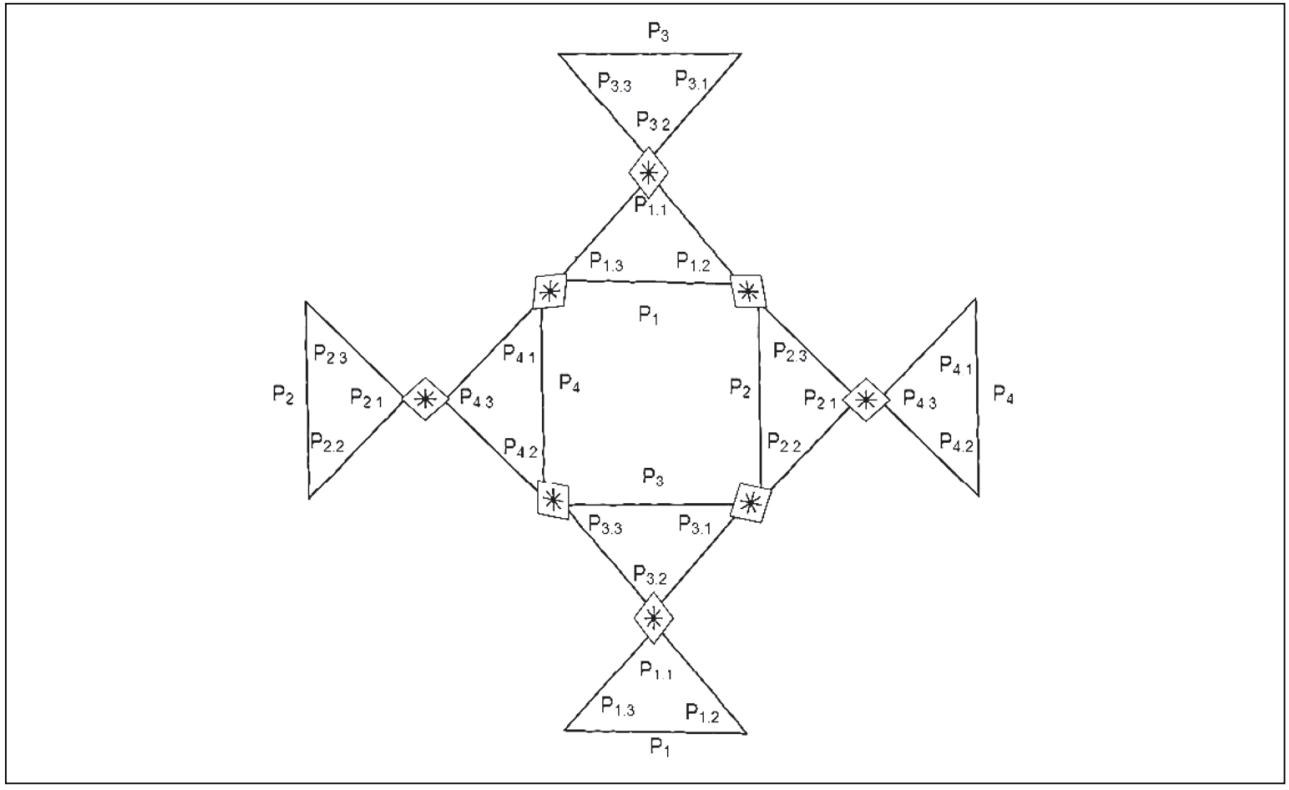

Source: own

changing managerial roles in organisations. Therefore, intentional references to the most classic approaches od $\mathrm{H}$. Mintzberg have been made.

\subsection{Managerial Roles}

In light of the foregoing reflections on the importance of multidimensional and variously interpreted space as an important category in the functioning of modern organisations, the Space Organisation Model (SOM) could discover new areas in terms of tasks performed by managers, or specific competencies. Embedding the issues regarding the roles and competencies of managers in organisations is a result of the approach associated with the commonly adopted classic functions of management: planning, organising, motivating, and controlling. Moreover, it seems that all suggestions or modifications in the framework of the managerial roles concept should refer to the classic and well-established concepts of Mintzberg (Mintzberg, 1971; 2009). As Gentry noted, "Mintzberg provided one of the most influential works on managerial roles" (Gentry et al., 2008, p. 168). The majority of research on managerial roles is often based on the set of roles developed by Mintzberg, therefore his output is the starting point or conceptual basis for research on this topic. (Tengblad, 2006; Kanter, 1989). His intention was to verify the managerial areas (functions) detailed by Fayol in the context of the real behaviour of managers in organisations. The achievements of classical thinkers, scientists and creators of the organisation and management sciences laid the foundation for the development of modern science in this field. As Peaucelle emphasises (2000, p. 453), "A number of elements of so-called 'Taylorian' enterprises are still present in modern companies and seem likely to remain for a long lime yet". Regarding the legacy of Taylor, Fayol and Weber, Schachter (2010), notice that "their thinking provided invaluable foundations for the field of organisation theory and their influence continues to this day" (2010, p. 38).

The managerial functions specified by Fayol (Fayol, 1979) have for decades been a reference point and a foundation for the interpretation of 
management processes (Schein, 2004). The role of manager may be described as a set of expected and desired behaviours resulting from their position in organisational social structure; it is most frequently associated with some kind of behavioural patterns. In relation to the emergence of the new phenomena that influence organisational behaviour and the work of managers, I suggest identification of the following areas of new managerial roles of CONTEXT INTERPRETER and SPACE PRODUCER. In justifying this suggestion, one may specifically refer to the suggested
Model of Space Organisation presented below (Tab. 5).

If we accept the above (Tab. 5) conceptualisation as legitimate, there remains only the issue of assigning the emerging areas of managerial roles in relation to Mintzberg's classical theory. Suggestions for assigning new areas in relation to interpersonal, informative, and decisive roles are presented in Tab. 6 .

Tab. 6 consists of a description of practical activity areas in a company that are associated with the spatial dimensions of the "new" roles of context interpreter and space producer.

\section{Tab. 5: "Spatial" Managerial Roles in reference to the Space Organisation Model (SOM)}

\begin{tabular}{l|l}
\multicolumn{1}{c|}{ New roles } & \multicolumn{1}{|c}{ References to Space Organisation Model (SOM) } \\
\hline CONTEXT INTERPRETER & $\begin{array}{l}\text { (P.1), (P1.1) and (P.3), (P3.2) } \\
\text { Topical space exists in close relation to internal organisational space. } \\
\text { This space defines the location of material objects or people in physical } \\
\text { organisational space within its boundaries. At the same time, this } \\
\text { configuration of objects determines the context of the space. }\end{array}$ \\
\hline SPACE PRODUCER & $\begin{array}{l}\text { (P.2), (P2.1) and (P.4), (P4.3) } \\
\text { Producing a space (creating a space) is directly related to network } \\
\text { space within the meaning of inter-organisational networks. For example, } \\
\text { in network space Global Production Networks arise from the } \\
\text { organisational point of view and the process of creating new space } \\
\text { through its "expansion", "extension", and "transformation". } \\
\text { The changes that occur in inter-organisational networks create new } \\
\text { space in many dimensions. }\end{array}$ \\
\hline CONTEXT INTERPRETER & $\begin{array}{l}\text { (P.2), (P2.2) and (P.3), (P3.1) } \\
\text { Local space in the sense of the physical location of a company } \\
\text { in a given territory directly interacts with the cultural space present } \\
\text { in a certain "place" of physical space. }\end{array}$ \\
\hline SPACE PRODUCER & $\begin{array}{l}\text { (P.3), (P3.3) and (P.4), (P4.2) } \\
\text { Contextual space - a space of cultural, social, and cognitive experience, } \\
\text { both for the social environment of the organisation and consumers - } \\
\text { directly interacts with the space of experience defined as the economy } \\
\text { of cyberspace experience phenomenon. }\end{array}$ \\
\hline SPACE PRODUCER & $\begin{array}{l}\text { (P.4), (P4.1) and (P.1), (P1.3) } \\
\text { Organisational structures as part of "organisational space" or its } \\
\text { form remain in relation to network architecture, primarily because } \\
\text { network architecture (e.g. the physical arrangement of the individual } \\
\text { elements of the technical infrastructure of a network) may influence } \\
\text { the organisational structure and its design, as well as the network } \\
\text { architecture itself. Its usage by organisations may be a prerequisite } \\
\text { for adopting specified organisational structures, e.g. so-called virtual } \\
\text { companies. }\end{array}$ \\
\hline INTERPRETER
\end{tabular}




\begin{tabular}{l|l}
$\begin{array}{c}\text { Managerial roles acc. } \\
\text { to H. Mintzberg }\end{array}$ & \multicolumn{1}{c}{ Area of practical activities of the suggested roles } \\
\hline Interpersonal roles & $\begin{array}{l}\text { Context interpreter } \\
\text { tasks associated with reading, interpretation of meanings and cultural } \\
\text { codes in the context of management in multicultural environments; } \\
\text { for example, in relation to the activities of transnational corporations; } \\
\text { tasks involving initiating and controlling cognitive processes based } \\
\text { on interdisciplinary and "contextually different" sets; for example, } \\
\text { in knowledge management processes in organisations; }\end{array}$ \\
\hline Decisional roles & $\begin{array}{l}\text { Space producer } \\
\text { - tasks (decisions) associated with a company's participation in inter- } \\
\text { organisational networks; } \\
\text { tasks associated with tasks (decisions) which relate to the degree } \\
\text { and scope of virtualisation of the company; } \\
\text { tasks (decisions) associated with the use of cyberspace as a new } \\
\text { "market space". }\end{array}$ \\
\hline
\end{tabular}

\section{Discussion and Conclusion}

In recent years, an increasing interest in space can be observed. Perhaps we have found ourselves right before a kind of "spatial shift" in organisational and management sciences (Ropo et al., 2015, p. 7). Because space is a term most commonly used as a metaphor, the author's intention was to avoid this trap through analysis grounded in the well-established scientific theories relating to space. The paper aims to develop the theory based on the conceptual model proposed. As Maclnnis notes, "conceptual papers are academic papers devoted purely to thought-based concepts that are devoid of data" (2011, p. 141). At the same time, he notes that conceptualisation "is the process of understanding a situation or a problem by abstractly identifying patterns or connections and key underlying properties" (2011, p. 140). One way of presenting conceptual thinking is visual representations, for example in the form of models. Referring to the research aim, regarding the identification of the category of space as an essential "variable" in relation to the management processes - four main categories have been identified that are a kind of "spatiality" dimensions in functioning of modern organisations: (P1) Space of organisation; (P2) Glocal space (between locality and globality); (P3) Contextual space; (P4) Cyberspace (virtual space). "Space Organisation Model" (SOM) was developed.
This graphical model (SOM), whose characteristics are related to a "fractal structure", was proposed exclusively for certain space structuralisation issues. Of course, the model's spatiality and geometry are not objective features; they are only an "innovative" method of visualisation. The article's contribution is to develop a conceptual proposal for a space model in the context of the functioning of contemporary organisations and management process in line with Whetten's emphasis that "If the theoretical model is a useful guide for research, by definition, all the relationships in the model have not been tested" (1989, p. 491). It seems that added value lies in proposing certain conceptual frameworks for exploring the question of space, its dimensions, and the way space exists in modern organizations. By applying the conceptual SOM model to the emergence of new organizational tasks and competences, New “Spacial” Managerial Roles, was proposed:

- context interpreter-concern: interpretation of cultural codes in multicultural environments; management in transnational corporations, management of cognitive and contextual knowledge processes.

- and space producer-concern: management in inter-organisational and global networks; management of virtualisation and e-business models. 
The presented theoretical experiment of the "Spatial" Managerial Roles could prove the usefulness of the proposed approach in further exploration of space issues in organisations and management processes. Therefore, the term of managerial "spatial roles" does not result directly from practical observation of behaviour, but from the conceptualisation of space concept as an important category in company's activity and thus in management processes.

The author is aware of limitations of this approach; however, he believes that the presented interdisciplinary approach and conceptualisation of spatiality in the context of organisations and management processes can be considered as a contribution to the contemporary academic debate in socio-economic science.

The research presented in this paper is the part of scientific project $n r$ 2017/25/B/ HS4/01007 financed by National Science Centre in Poland.

\section{References}

Antolín-Lopez, R., Martinez-del-Rio, J., José, J., Céspedes-Lorente, J., \& Pérez-Valls, M. (2015). The choice of suitable cooperation partners for product innovation: Differences between new ventures and established companies. European Management Journal, 33(6), 472-484. https://doi.org/10.1016/j. emj.2015.09.002.

Baudrillard, J. (1981). Simulacra and Simulation. Ann Arbor: University of Michigan Press. https://doi.org/10.3998/mpub.9904.

Beard, C., \& Price, I. (2010). Space, conversations and place: lessons and questions from organisational development. International Journal of Facility Management, 1(2), 1-14.

Beichler, J. (1981). The Ancient Greek Concept of Space. Scientific Thought I, Fall.

Billsberry, J., \& Birnik, A. (2010). Management as a contextual practice: the need to blend science, skills and practical wisdom. Organization Management Journal, 7(2), 171178. https://doi.org/10.1057/omj.2010.15.

Blake, A., \& Moseley, J. (2011). Frederick Winslow Taylor: One Hundred Years of Managerial Insight. International Journal of Management, 28(4), 346-353.

Bolin, M., \&Härenstam,A. (2008).AnEmpirical Study of Bureaucratic and Post-Bureaucratic Characteristics in 90 Workplaces. Economic and Industrial Democracy, 29(4), 541-564. https://doi.org/10.1177/0143831X08096228.

Boschma, R. A. (2005). Proximity and innovation. A critical assessment. Regional Studies, 39(1), 61-74. https://doi.org/10.1080/ 0034340052000320887.

Brunet-Thornton, R., \& Bureš, V. (2012). Cross-Cultural Management: Establishing A Czech Benchmark. E\&M Ekonomie a Management, 15(3), 46-62.

Cannon, J., Floyd, W., Kenyon, W., \& Parry, R. (1997). Hyperbolic Geometry. Flavors of Geometry. Cambridge: Cambridge University Press.

Carrincazeaux, C., Lung, Y., \& Vicente, J. (2008). The scientific trajectory of the French school of proximity: interaction- and institutionbasedapproachestoregional innovation systems. European Planning Studies, 16(5), 617-628. https://doi.org/10.1080/09654310802049117.

Castells, M. (2000). The Rise of the Network Society. Malden: Blackwell Publishers.

Caygill, H. (1995). A Kant Dictionary. The Blackwell Philosopher Dictionaries. Oxford: Blackwell Publishing.

Chan Kim, W., \& Mauborgne, R. (2005). Blue Ocean Strategy: How to Create Uncontested Market Space and Make Competition Irrelevant. Cambridge: Harvard Business Review Press.

Chanlat, J-F. (2013). Space, Organisation and Management Thinking: a Socio-Historical Perspective. In S. Clegg \& M. Kornberger (Eds.), Space, Organizations and Management Theory, Advances in Organization Studies. Frederiksberg: Liber \& Copenhagen Business School Press.

Clegg, S., \& Kornberger, M. (Eds.). (2013). Space, Organizations and Management Theory, Advances in Organization Studies. Frederiksberg: Liber \& Copenhagen Business School Press.

Coe, N. (2012). Geographies of production II. A global production network A-Z. Progress in Human Geography, 36(3), 389-402. https://doi. org/10.1177/0309132511402784.

Dale, K., \& Burrell, G. (2007). The Spaces of Organisation and the Organisation of Space: Power, Identity and Materiality at Work. Basingstoke: Palgrave Macmillan.

Deprez, F., \& Tissen, R. (2009). Creating Spatial Organizations. NRI Research Paper Series, 9(7), 1-55.

Derksen, M. (2014). Turning men into machines? Scientific management, industrial 
psychology and the human factor. Journal of the History of the Behavioral Sciences, 50(2), 148-165. https://doi.org/10.1002/jhbs.21650.

Descartes, R. (2008). Principles of Philosophy. New York: Barnes and Noble.

Fayol, H. (1979). Administration industrielle et générale. Paris: Dunod.

Ferraro, S. (2016). Frederick Taylor's other Principles. International Journal of Business and Social Science, 7(11), 24-27.

Flyverbom, M., Leonardi, P. M., Stohl, C., \& Stohl, M. (2016). The management of visibilities in the digital age. International Journal of Communication, 10, 98-109.

Foucault, M. (1984). Of Other Spaces, Heterotopias. Architecture, Mouvement, Continuité, 5, 46-49.

Fraassen van, B. (1985). An introduction to the philosophy of time and space. New York: Columbia University Press.

Gentry, W., Harris, L., Baker, B., \& Leslie, J. (2008). Managerial skills: what has changed since the late 1980s. Leadership \& Organization Development Journal, 29(2), 167-181. https://doi.org/10.1108/01437730810852506.

Gereffi, G., Humphrey, J., \& Sturgeon, T. (2005). The governance of global value chains. Review of International Political Economy, 12(1), 78-104. https://doi. org/10.1080/09692290500049805.

Giddens, A. (1990). The Consequences of Modernity. Stanford: Stanford University Press.

Graeber, D. (2015). The Utopia of Rules. On Technology, Stupidity, and the Secret Joys of Bureaucracy. Brooklyn, London: Melville House Publishing.

Greenberg, M. J. (1994). Euclidean and non-euclidean geometries. Development and history (3rd ed.). New York: W. H. Freeman \& Co.

Halford, S. (2004). Towards a Sociology of Organizational Space. Sociological Research Online, 9(1). https://doi.org/10.5153/sro.885.

Heinzmann, G., \& Stump, D. (2014). Henri Poincaré. In N. Zalta (Ed.), The Stanford Encyclopedia of Philosophy. Stanford: Stanford University. Available from http://plato.stanford. edu/archives/spr2014/entries/poincare/.

Hernes, T. (2004). Spatial Construction of Organization. Amsterdam: John Benjamins. https://doi.org/doi.org/10.1075/aios.12.

Hughes,A., \& Reimer,A.S.(2004). Geographies of Commodity Chains. London: Routledge. https://doi.org/10.20592/jaeg.51.1_131.
Hussey, E. (1983). Aristotle Physics Books III and IV. Oxford: Clarendon Press.

Jones, A. (2009). Theorizing global business space. Geografiska Annaler B: Human Geography, 91(3), 203-218. https://doi. org/10.1111/j.1468-0467.2009.00315.x.

Kačerauskas, T. (2016). The paradoxes of creativity management. E\&M Ekonomie a Management, 19(4), 33-43. https://doi. org/10.15240/tul/001/2016-4-003.

Kant, I. (1992). On the Form and Principles of the Sensible and the Intelligible World. In Theoretical Philosophy (pp. 1755-1770) (D. Walford \& R. Meerbote, Trans.). Cambridge: Cambridge University Press.

Kanter, R. M. (1989). The new managerial work. Harvard Business Review, 67(6), 85-92.

Kornberger, M., \& Clegg, S. (2004). Bringing Space Back In: Organizing the Generative Building. Organization Studies, 25(7), 1095-1114. https://doi.org/10.1177/0170840604046312.

Lefebvre, H. (1991). The production of space. Malden: Blackwell Publishing.

Lekanne Deprez, F., \& Tissen, R. (2008). Towards a Spatial Theory of Organizations, Creating new organizational forms to improve business performance [NRG Working Paper No. 08-04]. Nyenrode: Nyenrode Business University. https://doi.org/10.2139/ssrn.1105664.

Lenz, B. (1997). Das Filière-Konzept als Analyseinstrument der organisatorischen und räumlichen Anordnung von Produktions und Distributionsprozessen. Geographische Zeitschrift, 85(1), 20-33.

Lorenzen, M. (2007). Social capital and localised learning: Proximity and place in technological and institutional dynamics. Urban Studies, 44(4), 799-817. https://doi. org/10.1080/00420980601184752.

Maclnnis, D. (2011). A Framework for Conceptual Contributions in Marketing. Journal of Marketing, 75(4), 136-154. https://doi. org/10.1509/jmkg.75.4.136.

Mandelbrot, B. (1982). The Fractal Geometry of Nature. New York: W. H. Freeman and Co.

Massey, D. (2005). For Space. Los Angeles, London, New Delhi: SAGE Publications.

Mayo, E. (1933). The human problems of an industrial civilization. Cambridge: Harvard.

Mintzberg, H. (2009). Managing. San Francisco: Berrett-Koehler Publishers Inc.

Mintzberg, H. (1971). Managerial Work: Analysis from Observation. Management Science, 18(2), 97-110. 
Newton, I. (1999). Mathematical Principles of Natural Philosophy. Oakland: University of California Press.

Nonaka, I., \& Konno, N. (1998). The concept of "Ba": Building a foundation for knowledge creation. California Management Review, 40(3), 40-54. https://doi.org/10.2307/41165942.

Nonaka, I., \& Takeuchi, H. (1995). The knowledge creating company: how Japanese companies create the dynamics of innovation. New York: Oxford University Press.

Peaucelle, J.-L. (2000). From Taylorism to post-Taylorism: Simultaneously pursuing several management objectives. Journal of Organizational Change Management, 13(5), 452-467. https://doi.org/10.1108/09534810010377426.

Price, I. (2007). Lean assets: new language for new workplaces. California Management Review, 49(2), 102-118. https://doi.org/10.2307/41166385.

Ropo, A., De Paoli, D., Solovaara, P., \& Sauer, E. (2015). Why does space need to be taken seriously in leadership and organization studies and practice? In A. Ropo, P. Solovaara, D. De Paoli, \& E. Sauer (Eds.), Leadership in spaces and places. Cheltenham: Edward Elgar.

Roth, S., Sales, A., \& Kaivo-oja, J. (2017). Multiplying the division of labor: Functional differentiation of the next key variables in management research. Systems Research and Behavioral Science, 34(2), 195-207. https://doi.org/10.1002/sres.2452.

Schachter, H. (2010). The role played by Frederick Taylor in the rise of the academic management fields. Journal of Management History, 16(4), 437-448. https://doi. org/10.1108/17511341011073924.

Schein, E. H. (2004). Organizational Culture and Leadership. San Francisco: Jossey-Bass, A Wiley Imprint.

Schemmel, M. (2016). Historical Epistemology of Space: from Primate Cognition to Spacetime Physics. Cham, Heidelberg, New York: Springer. https://doi.org/10.1007/978-3319-25241-4.

Schlunze, R., Agola, N., \& Baber, W. (2012). Spaces of International Economy and Management. Launching New Perspectives on Management and Geography. Palgrave Macmillan: Basingstoke.
Shafritz, J., Ott, S., \& Jang, Y. (2010). Classics of Organization Theory. Boston: Cengage Learning.

Taylor, F. W. (1967). The Principles of Scientific Management. New York: Norton Library.

Taylor, S., \& Spicer, A. (2007). Time for space: A narrative review of research on organizational space. International Journal of Management Reviews, 9(4), 325-346. https://doi.org/10.1111/j.1468-2370.2007.00214.x.

Tengblad, S. (2006). Is there a 'new managerial work'? A comparison with Henry Mintzberg's classic study 30 years later. Journal of Management Studies, 43(7), 1437-1461. https://doi.org/10.1111/j.14676486.2006.00651.x.

Vaujany, de F. X., \& Mitev, N. (2013). Introduction: Space in Organisation and Sociomateriality. In F. X. de Vaujany \& N. Mitev (Eds.), Materiality and Space: Organizations, Artefacts and Practices (pp. 1-21). New York: Palgrave Macmillan. https://doi. org/10.1057/9781137304094 1.

Weber, M. (1947). The Theory of Social and Economic Organization. New York: Free Press.

Whetten, D. (1989). What Constitutes a Theoretical Contribution? Academy of Management Review, 14(4), 490-495. https://doi.org/10.5465/amr.1989.4308371.

Vetráková, M., \& Smerek, L. (2016). Diagnosing Organizational Culture in National and Intercultural Context. E\&M Ekonomie a Management, 19(1), 62-72. https://doi. org/10.15240/tul/001/2016-1-005.

Yeung, H. W.-C., \& Coe, N. (2014). Toward a Dynamic Theory of Global Production Networks. Economic Geography, 91(1), 29-58. https://doi.org/10.1111/ecge.12063.

Zhang, Z., Spicer, A., \& Hancock, P. (2008). Hyper-organizational space in the work of J. G. Ballard. Organization, 15(6), 889-910. https://doi.org/10.1177/1350508408095819.

dr hab. Piotr Pachura, PhD. Częstochowa University of Technology Faculty of Management Poland piotr.pachura@wz.pcz.pl 


\section{Abstract}

\section{SPACE IN ORGANISATION AND MANAGEMENT. INTERDISCIPLINARY PERSPECTIVE IN MODELLING TOWARDS NEW MANAGERIAL ROLES}

\section{Piotr Pachura}

The concept of space is a category that has been present in science since antiquity. Experiencing "spatiality" of the world was one of key experiences of human being throughout the development of Civilisation. Space was of primary concern to physicists, mathematicians, and philosophers of nature. Socio-economic sciences treated the issue of space primarily in terms of distance, possibly as a configuration of material objects.

To a great extent, modernist interpretations of organisation and management processes have been limited to the relationship between "an organisation and its environment". The concept of space is trapped in metaphor. It was assumed that if organisation by definition may be described without references to space, however the way organisation is functioning has always a reference to space.

Simultaneously, organisations are increasingly struggling with different spaces, especially in the face of the "localness-globalness" dichotomy, or virtual and network spaces.

This paper attempts to achieve an interdisciplinary conceptualisation of space issues in the context of organisation and management sciences. A conceptual innovative model of space dimensions for organizations was developed, identifying: (1) Organisational space; (2) Glocal space (between locality and globality); (3) Topical (contextual) space and (4) Cyberspace, so-called "Space Organisation Model" (SOM). In the latter part of the paper, a theoretical experiment based on deductive substantiation is presented which focuses on the meso-level, with a view to proposing new "spatial" managerial roles in organisations. The research logic presented in this paper, leading from wide interdisciplinary studies through construction of a conceptual model as the meta-level (SOM), to theoretical experiments at the micro-level (New Managerial Roles).

Key Words: Space, organisation, management, conceptualisation, ontology of space, managerial roles.

JEL Classification: C9, D23, M1, O31, M21, E71.

DOI: 10.15240/tul/001/2019-3-003 